Pengaruh Terapi Jus Sirsak Terhadap Penurunan Kadar Asam Urat Pada Lansia Di UPT Panti Sosial Tresna Werdha Mulia Dharma Provinsi Kalimantan Barat(Lili Santi)

\title{
PENGARUH TERAPI JUS SIRSAK TERHADAP PENURUNAN \\ KADAR ASAM URAT PADA LANSIA DI UPT PANTI SOSIAL TRESNA WERDHA MULIA DHARMA PROVINSI KALIMANTAN BARAT
}

The Influence Of Soursop Juice Therapy Against A Decline In The Levels Of Uric Acid In Elderly In UPT Panti Social Tresna Werdha Venerable Dharma Province Of West Kalimantan

\author{
Oleh: \\ Lili Santi* \\ Ramadhaniyati** \\ Herman***
}

\begin{abstract}
Abstrak
Latar Belakang: Selain penyakit hipertensi, rematik, darah rendah, dan diabetes mellitus, penyakit yang sering dialami lansia adalah asam urat. Faktor yang menyebabkan penyakit asam urat yaitu faktor pola makan, faktor usia, dan lainlain. Obat alami dan paling mujarab untuk mengobati asam urat adalah buah sirsak atau lebih dikenal dengan nama buah nangka belanda.Tujuan: penelitian ini untuk mengetahui karakteristik responden, Pengaruh terapi jus sirsak sebelum dan setelah terapi jus sirsak untuk menurunkan kadar asam urat pada lansia di UPT Panti Sosial Tresna Werdha Mulia Dharma Provinsi Kalimantan Barat. Metode: penelitian ini menggunakan Pre eksperimen design dengan desain penelitian pre and post test without control. Populasi dalam penelitian ini adalah lansia di UPT Panti Sosial Tresna Wherda Mulia Dharma Provinsi Kalimantan Barat yang berjumlah 65 orang. Teknik pengambilan sampel dalam penelitian menggunakan metode Total sampling dimana jumlah sampel yang digunakan dalam penelitian ini berjumlah 18 orang. Hasil: sudah dianalisis dengan Uji Wilcoxon terdapat pengaruh terapi jus sirsak terhadap penurunan kadar asam urat pada lansia di UPT Panti Sosial Tresna Werdha Mulia Dharma Provinsi Kalimantan Barat dimana diperoleh nilai $p=0,007$ hasil ini berarti nilai $p$ lebih kecil dari $(0,05)$ menunjukan terjadi penurunan kadar asam urat pada responden setelah diberikan terapi jus sirsak. Kesimpulan: ada pengaruh antara terapi jus sirsak terhadap penurunan kadar asam urat pada lansia di UPT Panti Sosial Tresna Werdha Mulia Dharma Provinsi Kalimantan Barat. Saran: Terapi jus sirsak dapat diterapkan dikomunitas untuk meminimalisasi tingkat kadar asam urat yang dialami oleh lansia sehingga dapat meningkatkan derajat kesehatannya.
\end{abstract}

Kata Kunci : Lansia, Asam Urat, Jus Sirsak 
*Mahasiswi Prodi Keperawatan Fakultas Kedokteran Universitas Tanjungpura, Pontianak

**Dosen Pembimbing I Skripsi, Keperawatan STIK Muhammadiyah Pontianak

***Dosen Pembimbing II Skripsi, Keperawatan Fakultas Kedokteran Universitas Tanjungpura, Pontianak

\begin{abstract}
Background: In addition to hypertension, rheumatism, low blood, and diabetes mellitus, a disease often experienced by the elderly is uric acid. Factors that cause uric acid are factors such as diet factor, age factor, and others. The natural and most efficacious remedy for treating uric acid is soursop fruit or better known by the name of the Dutch jackfruit. Purpose: This research to know the characteristics of respondents, the effect of therapy soursop juice before and after the therapy soursop to reduce the level of uric acid in the elderly in the UPT of the social orphanage Tresna Werdha Mulia Dharma province West Kalimantan. Method: This study uses pre experimental design with pre and post test without control of design research. The population in this study is the parents in the orphanage UPT Tresna Wherda mulia Dharma province West Kalimantan which amounted to 65. Sampling techniques in research using the Total sampling method whereby the number of samples used in this study amounted to 18 people. Result: Already analyzed Wilcoxon test there is the influence of therapy soursop juice to decrease the level of uric acid in the elderly in UPT Social orphanage Tresna Werdha Mulia Dharma province West Kalimantan where the value obtained $p=0.007$ This result means more $P$ value Small of $(0.05)$ showed a decrease in uric acid levels in respondents after being given soursop juice therapy. Conclusion: There is a therapeutic influence of soursop juice to decrease uric acid levels in the elderly in social orphanage Tresna Werdha Noble Dharma Province of West Kalimantan. Suggestion: Therapy soursop juice can be applied in the community to minimize levels of uric acid levels experienced by the elderly so as to increase the degree of health.
\end{abstract}

Key words: Elderly, Uric Acid, Soursop Juice

\footnotetext{
*Nursing Student at Faculty of Medicine of Tanjungpura University, Pontianak

**1st Thesis Supervisor, Nursing lecturer in STIK Muhammadiyah Pontianak

*** 2nd Thesis Supervisor, Nursing lecturer in Faculty of Medicine Tanjungpura

University, Pontianak
} 
Pengaruh Terapi Jus Sirsak Terhadap Penurunan Kadar Asam Urat Pada Lansia Di UPT Panti Sosial Tresna Werdha Mulia Dharma Provinsi Kalimantan Barat(Lili Santi)

\section{PENDAHULUAN}

Lanjut usia dipandang sebagai masa degenerasi biologis yang disertai oleh berbagai penderitaan akibat berbagai macam penyakit yang menyertai proses menua, tetapi merupakan tahap lanjut dari suatu proses kehidupan yang ditandai dengan penurunan kemampuan untuk tubuh beradaptasi dengan stress lingkungan. Penurunan kemampuan berbagai organ, fungsi, dan sistem tubuh itu bersifat alamiah atau fisiologis. Penurunan tersebut disebabkan berkurangnya jumlah dan kemampuan sel tubuh. Pada umumnya tanda proses menua mulai tampak sejak usia 45 tahun dan akan menimbulkan masalah pada usia sekitar 60 tahun (Maryam, 2008).

Menurut Susenas 2012, angka kesakitan penduduk lansia Indonesia sebesar 26,93\% artinya setiap 100 orang lansia terdapat 27 orang diantaranya mengalami sakit dan perbedaan lansia yang mengalami keluhan kesehatan berdasarkan jenis kelamin pria 50,22\% dan wanita
53,74\%. Di dalam Susenas dikumpulkan informasi mengenai jenis keluhan kesehatan lansia yang paling tinggi $(32,99 \%)$ adalah jenis keluhan diantaranya keluhan yang seperti asam urat, darah tinggi, rematik, darah rendah, dan diabetes-mellitus (Abikusno, 2013).

Pada lansia dengan asam urat menimbulkan masalah fisik sehari-hari seperti: gangguan aktivitas, gangguan pola tidur, gangguan rasa nyeri, dan sebagainya, sehingga pemeliharaan kesehatan lansia dengan asamurat harus ditingkatkan agar tidak mengancam jiwa penderitanya dan menimbulkan ketidaknyamanan yang disebabkan oleh penyakit asam urat (Bandiyah, 2009).

Berbagai manfaat sirsak untuk terapi antara lain pengobatan batu empedu, antisembelit, asam urat, dan meningkatkan selera makan. Selain itu, kandungan seratnya juga berfungsi untuk mempelancar pencernaan, terutama untuk pengobatan sembelit 
(susah buang air besar). Obat alami dan paling mujarab untuk mengobati asam urat adalah buah sirsak atau lebih dikenal dengan nama buah nangka belanda. Jika terkena asam urat, langsung minum/makan buah sirsak tersebut (Astika, 2013).

Tujuan Penelitian ini Untuk mengetahui pengaruh terapi jus sirsak terhadap penurunan kadar asam urat pada lansiadi UPT Panti Sosial Tresna Werdha Mulia Dharma Provinsi Kalimantan Barat.

\section{METODE PENELITIAN}

Dalam penelitian ini menggunakan jenis penelitian kuantitatif dengan menggunakan desain penelitian Pre eksperimen design (non designs). Desain ini dikatakan sebagai preexperimental design karena belum merupakan eksperimen sungguhsungguh karena masih terdapat variabel luar yang ikut berpengaruh terhadap terbentuknya variabel dependen. Rancangan ini berguna untuk mendapatkan informasi awal terhadap pertanyaan yang ada dalam penelitian (Sugiyono, 2010).

Penelitian ini menggunakan desain pre and post test without control, yaitu peneliti hanya melakukan intervensi pada suatu kelompok tanpa pembanding. Efektifitas perlakuan dengan cara membandingkan nilai pre test dan post test.

Penelitian ini dilaksanakan untuk mengetahui pengaruh variabel bebas (independen) yaitu terapi jus sirsak ter hadap variabel terikat (dependen) yaitu kadar asam urat sebelum dan sesudah perlakuan/intervensi pada lansia di UPT Panti Sosial Tresna Werdha Mulia Dharma Provinsi Kalimantan Barat.

\section{HASIL PENELITIAN}

UPT Panti Sosial Tresna Werdha Mulia Dharma Provinsi Kalimantan Barat terletak di Jalan Adisucipto Km. 12,6 Desa Arang Limbung Kecamatan Sungai Raya Kabupaten Kubu Raya dengan luas area $8.975 \mathrm{~m}^{2}$. Panti Sosial Tresna Werdha Mulia Dharma dilengkapi dengan sarana yaitu 10 wisma, 1 kantor, 1 aula, 4 rumah dinas, 1 poliklinik, 1 dapur, 1 lokal kerja, 1 gudang dan 1 musholla. Prasarana dapat berupa pelayanan kesehatan dan pemakaman. Panti ini memiliki kapasitas untuk menampung 90 orang lansia dengan berbagai karakteristik yang dimiliki oleh lansia. 
Tabel 4.1 Distribusi Frekuensi dan Persentase Karakteristik Responden Berdasarkan Umur dan Jenis Kelamin $(\mathrm{N}=18)$

\begin{tabular}{ccc}
\hline Karakteristik & F & $(\%)$ \\
\hline Jenis Kelamin & & \\
- Perempuan & 10 & 55,6 \\
- Laki-laki & 8 & 44,4 \\
\hline Umur & 12 & \\
$-\quad 60-69$ tahun & 6 & 66,7 \\
$-\quad 70-79$ tahun & & 33,3 \\
\hline
\end{tabular}

Berdasarkan hasil tabel 4.1 diatas Untuk usia terbanyak yaitu dari rentang menunjukan bahwa jumlah responden umur 60-69 tahun sebanyak 12 berjenis kelamin perempuan yaitu (66,7\%), sedangkan rentang umur 70sebanyak $10(55,6 \%)$ dan responden 79 tahun sebanyak $6(33,3 \%)$.

laki-laki sebanyak $8(44,4 \%)$.

Tabel 4.2 Hasil Analisis Uji Wilcoxon Kadar Asam Urat Sebelum Dan Dua Minggu Sesudah Terapi Jus Sirsak

\begin{tabular}{lccccc}
\hline \multicolumn{1}{c}{ Variabel Mean \pm} & \multicolumn{2}{c}{ SD } & Median & Min-Max & P Value \\
\hline $\begin{array}{l}\text { Kadar Asam Urat Sebelum } \\
\text { terapi }\end{array}$ & 7,55 &, 40 & 7,50 & $7,10-8,70$ & 0,007 \\
$\begin{array}{l}\text { Kadar Asam Urat setelah Dua } \\
\text { Minggu terapi }\end{array}$ & 7,06 &, 56 & 7,21 & $6,00-7,70$ & \\
\hline
\end{tabular}

Berdasarkan hasil analisis tabel sirsak yaitu 7,06, median 7,21 dengan diatas, didapatkan bahwa rata-rata kadar standar deviasi 0,56 dengan nilai minasam urat sebelum, terapi jus sirsak di max sebelum intervensi 7,10-8,70 dan UPT Panti Sosial Tresna Werdha Mulia dua minggu setelah intervensi 6,00-7,70 Dharma Provinsi Kalimantan Barat setelah diberikan intervensi serta yaitu 7,55, median 7,50 dengan standar didapatkan nilai $\mathrm{p}=0,007$. Berdasarkan deviasi 0,40 dan rata-rata kadar asam data diatas dapat disimpulkan bahwa urat dua minggu sesudah terapi jus nilai $\mathrm{p}(0,007)<0,05$ yang artinya Ho 
ditolak dan ada pengaruh terapi jus urat di UPT Panti Sosial Tresna sirsak terhadap kadar asam urat pada Werdha Mulia Dharma Provinsi lansia di UPT Panti Sosial Tresna Kalimantan Barat lebih banyak dialami Werdha Mulia Dharma Provinsi oleh perempuan dibandingkan dengan Kalimantan Barat.

\section{PEMBAHASAN}

Berdasarkan hasil penelitian yang dilakukan di UPT Panti Sosial Tresna Werdha Mulia Dharma Provinsi Kalimantan Barat, didapatkan bahwa jumlah usia terbanyak yang mengalami asam urat adalah rentang usia 60-69 tahun dan usia paling sedikit yang mengalami asam urat yaitu rentang usia 70-79 tahun. Berdasarkan hasil analisis peneliti hal ini terjadi selain karena pengaruh usia dimana semakin bertambahnya usia maka resiko terjadinya asam urat juga akan semakin tinggi selain itu pola makan yang tidak terkontrol serta gaya hidup yang salah juga mempengaruhi terjadinya asam urat.

Berdasarkan hasil penelitian yang dilakukan di UPT Panti Sosial Tresna Werdha Mulia Dharma Provinsi Kalimantan Barat didapatkan frekuensi responden yang berjenis kelamin perempuan sebanyak $10(55,6 \%)$ dan laki-laki yang mengalami asam urat sebanyak $8(44,4 \%)$. Penderita asam laki-laki. Hal tersebut dapat terjadi selain disebabkan oleh faktor hurmonal, dimana usia manopause secara normal biasanya terjadi antara usia 40-60 tahun, setelah manopause wanita cenderung memiliki kadar asam urat yang tinggi karena perubahan hormonal yaitu kurangnya kadar ekstrogen dalam darah.

Berdasarkan hasil penelitian yang dilakukan di UPT Panti Sosial Tresna Wherda Mulia Dharma Provinsi Kalimantan Barat didapatkan ada pengaruh kadar asam urat sebelum dan dua minggu setelah diberikan intervensi dengan terapi jus sirsak dengan nilai $\mathrm{p}$ menunjukan 0,007 yang artinya ada hubungan terhadap hasil pengukuran pretes dan postest.

\section{KESIMPULAN}

Berdasarkan hasil penelitian yang dilakukan di UPT Panti Sosial Tresna Wherda Mulia Dharma Provinsi Kalimantan Barat didapatkan ada pengaruh kadar asam urat sebelum, dan dua minggu setelah diberikan intervensi dengan terapi jus sirsak 
dengan nilai $\mathrm{p}$ menunjukan 0,007 yang pengukuran pretes dan postest. artinya ada prngaruh terhadap hasil

\section{DAFTAR PUSTAKA}

1. Abikusno. 2013. www.depkes.go.id.Buletin Jendela Data Dan Informasi Kesehatan.

2. Astika, Ayu. 2013. Khasiat Selangit Manggis dan Sirsak Tumpas Beragam Penyakit. Araska. Yogjakarta.

3. Bandiyah, Siti. 2009. Lanjut Usia Dan Keperawatan Gerontik. Yogyakarta: Muha Medika

4. Maryam, Siti. 2008. Mengenal Usia Lanjut Dan Perawatannya. Jakarta: Salemba Medika

5. Sugiyono, Dr. 2010. Metode penelitian Kuantitatif Kualitatif dan R\&D, Penerbit Alfabeta

6. SUSENAS. (2012). Badan Pusat Statistik 2012. Jakarta. 